\title{
Evaluation of Disaster Simulation: Learning Process, Satisfaction, and Self-Confidence among Nursing Students
}

\author{
Etika Emaliyawati $^{1,2 *}$ D, Kusman Ibrahim $^{3}$ D, Yanny Trisyani $^{1}$ D, Ristina Mirwanti ${ }^{1} \mathbb{D}$, Sri Utami Dewi ${ }^{4}$, Tri Wahyu Murni ${ }^{5}$ \\ ${ }^{1}$ Department of Critical Care and Emergency Nursing, Faculty of Nursing, Universitas Padjadjaran, Bandung, Indonesia; ${ }^{2}$ Doctoral \\ Study Program, Faculty of Medicine, Universitas Padjadjaran, Bandung, Indonesia; ${ }^{3}$ Department of Medical Surgical Nursing, \\ Faculty of Nursing, Universitas Padjadjaran, Bandung, Indonesia; ${ }^{4}$ Under Graduate Program, Faculty of Nursing, Universitas \\ Padjadjaran, Bandung, Indonesia; ${ }^{5}$ Department of Surgeon, Sub-Devision of Cardiovascular Thorax Surgeon, Universitas \\ Padjadjaran, Bandung, Indonesia
}

Edited by: Mirko Spirosk Citation: Emaliyawati E, Ibrahim K, Trisyani Y, Mirwan R, Dewi SU, Murni TW. Evaluation of Disaster Simulation: Learning Process, Satisfaction, and Self Confidence amon Nursing Students. Open Access Maced J Med Sci. 2021 Nov 12; 9(T6):26-30. https://doi.org/10.3889/oamjms.2021.7317 Keywords: Satisfaction; Nursing students; Confidence; Disaster simulation *Correspondence: Etika Emaliyawal, Department Critical Care and Emergency Nursing, Faculty of Nursing, Program, Faculty of Medicine Universitas Padjadjar Bandung, Indonesia. E-mail: etika@unpad.ac.jid Received: 15 -Sep-202 Revised: 05-Oct-202 Accepted: 02-Nov-2021
Copyright: ๑ 2021 Etika Emaliyawati, Kusman Ibrahim, opyright: @ 2021 Etika Emaliyawati, Kusman Ibrahim,
Yanny Trisyani, Ristina Mirwanti, Sri Utami Dewi, Tr Wahyu Murni Funding: Universitas Padjadjaran funded the study with the Doctoral Dissertation Research Program schem Competing Interests: The authors have declared that competing inted that no Open Access: This is an open-access article distributed under the terms of the Creative Commons AttributionNonCommercial 4.0 International License (CC BY-NC 4.0)Edited by: https://publons.com/researcher/391987/ mirko-spiroski

\begin{abstract}
BACKGROUND: An inappropriate learning process can affect student satisfaction and self-confidence. Satisfaction and self-confidence are important components in the success of the disaster simulation learning process.

AIM: This study aims to determine the relationship between the disaster simulation learning process with student satisfaction and student confidence.

METHODS: It was a descriptive correlational study. A total of 144 respondents were obtained by response rate of $95.4 \%$. This study used a disaster simulation evaluation instrument. The data were analyzed using the Pearson correlation test with significance level of $95 \%$.

RESULTS: The study showed that there was a significant relationship between the disaster simulation learning process and student satisfaction $(r=0.827 ; p<0.000)$ and self-confidence $(r=0.815 ; p<0.000)$.

CONCLUSION: The learning process that is applied should use learning strategies that can increase student activity in conducting disaster simulations so that nursing students can feel satisfied and confident about learning disaster simulations and become volunteers.
\end{abstract}

\section{Introduction}

The world of health, especially nursing, applies simulation methods as a learning method to equip clinical skills before students go directly to real situations in the field. Simulation learning is a learning method through behavior as if in a real disaster event [1]. Disaster simulations make students play an active role in the learning process and are able to make students concentrate on understanding materials related to disaster nursing [2].

Disaster simulation is an excellent learning method in increasing student satisfaction with the disaster nursing learning process and increasing selfconfidence in providing treatment to victims [3]. The research supported by Zapko et al. (2017) revealed that disaster simulation learning gave a positive response to satisfaction and self-confidence [4]. Students feel comfortable and benefit a lot from the implementation of disaster simulation learning. In addition, disaster simulation can train critical thinking skills and students readiness to deal with emergencies [5].

Several state universities in Indonesia have implemented disaster simulation learning methods [6]. The simulation learning method in this disaster nursing course is designed to involve the active participation of students. This is one of the learning strategies other than the lecture method, where the lecture method tends to make students less involved in the learning process. [7]. Students' lack of active participation in the learning process in class will affect student activity in conducting disaster simulations [8] and will affect student satisfaction and confidence [9].

Disaster simulation learning is made to resemble natural disaster conditions, using human simulators or manikins as victims so that students feel the natural disaster. Satisfaction is an important component in determining the success of the learning process and as a positive reinforcement in building student confidence when providing care to 
patients [10]. A nurse or prospective nurse must have a high level of confidence in their competence [11]. The American Association of Colleges of Nursing supports nursing students to have a high level of confidence in communication, psychomotor skills as a professional nurse development [12].

The better the implementation of the disaster simulation learning process, the students will feel satisfied and confident. This will be very useful when students are involved in natural disaster conditions as volunteers [13]. Thus, the purpose of this study is to examine the relationship between the disaster simulation learning process with student satisfaction and confidence.

\section{Methods}

The design of this research was descriptive quantitative with a correlation analysis method. The population in this study were active students of the 2016 undergraduate program, Faculty of Nursing, Padjadjaran University, Jatinangor, and Pangandaran campuses, amounting to 151 people with a total of 144 respondents. The sampling technique is total sampling with a response rate of $95.4 \%$.

This study uses a disaster simulation evaluation instrument, a modified and combined result of the Educational Practices Questionnaire (EPQ) and Student Satisfaction and Self Confidence in Learning (SSS). The EPQ instrument to measure the learning process consists of 17 statement items. While the SSS instrument to measure satisfaction and self-confidence consists of 13 statement items. The total statement items on the instrument are $\mathbf{3 0}$ statement items.

The disaster simulation evaluation instrument has been tested for validity using construct validity and reliability tests on 30 students of the Faculty of Nursing, University of Padjadjaran, for the professional program. The validity results obtained are all valid statement items with a calculated $r$-value $>r$ table value $(r$ table $=0.361$ with a significance value of 0.05 ). While the weight of Cronbach's alpha 0.953 means a reliable instrument.

Before analyzing the data, the researchers conducted a data normality test using the KolmogorovSmirnov test. The results of the normality test of the disaster simulation learning process, satisfaction, and confidence were normally distributed (significance value $0.200>0.05$ ). Then, the data were analyzed using bivariate correlation to explain the relationship between the variables of the learning process, satisfaction, and self-confidence. Bivariate analysis using the Pearson correlation test, due to parametric data (normally distributed) and interval scale data. This research was conducted after obtaining an ethical exemption from the Research Ethics Committee of the Ministry of Education and Culture, Universitas Padjadjaran with Number.365/ UN.6.KEP/EC/2020.

\section{Results}

The results of the study in Table 1 show the characteristics of the respondents. The results obtained that most of the respondents $(90.3 \%)$ came from the Faculty of Nursing, Jatinangor campus, and most respondents were female (90.3\%). For the Grade Point Average (GPA), most respondents (95.1\%) obtained a GPA in the range of 3.00-4.00. Based on the experience of attending seminars/workshops, most respondents $(61.1 \%)$ have never participated in meetings/workshops on disaster management or disaster emergencies. Based on experiencing a disaster, most of the respondents $(81.9 \%)$ have never experienced a disaster. For the experience of being a volunteer, most of the respondents (83.3\%) did not have experience as a disaster volunteer and most of the respondents $(97.9 \%)$ needed additional training to improve skills related to disaster nursing.

Table 1: Frequency distribution of respondents demographic ( $n=144)$

\begin{tabular}{lll}
\hline Category & $\mathrm{n}$ & $\%$ \\
\hline Campus's location & 130 & 90.3 \\
$\quad$ Jatinangor & 14 & 9.7 \\
$\quad$ Pangandaran & & \\
Gender & 14 & 9.7 \\
$\quad$ Male & 130 & 90.3 \\
$\quad$ Female & & \\
Grade Point Average & 0 & 0 \\
$\quad 2.00-2.49$ & 7 & 4.9 \\
$2.50-2.99$ & 137 & 95.1 \\
$\quad 3.00-4.00$ & & \\
Seminar and workshop about disaster management & 88 & 61.1 \\
$\quad$ Never & 56 & 38.9 \\
$\quad$ Ever & & \\
Disaster event & 118 & 81.9 \\
$\quad$ Never & 26 & 18.1 \\
$\quad$ Ever & & 83.3 \\
Experience as disaster volunteers & 120 & 16.7 \\
$\quad$ Never & 24 & \\
Ever & & \\
\hline
\end{tabular}

Table 2 shows the results of the analysis of the relationship between the disaster simulation learning process and nursing student satisfaction, the value of $r=0.827$ and $p<0.000$, which indicates a relationship between the learning process variables and student satisfaction and the strength of the relationship was very strong. In addition, Table 2 shows a relationship between the variables of the learning process and the

Table 2: The relationship of the disaster simulation learning process to the satisfaction and confidence of nursing students

\begin{tabular}{lll}
\hline Category & $\mathrm{n}$ & $\%$ \\
\hline Additional Exercises to Improve Student Skills & & \\
Related to Disaster Nursing & & \\
Yes & 141 & 97.9 \\
No & 3 & 2.1 \\
Variable & Satisfaction & Confidence \\
Learning process & $r=0.827 ; p=0.000$ & $r=0.815 ; p=0.000$ \\
\hline
\end{tabular}


self-confidence of nursing students, and the strength of the relationship is very strong $(r=0.815$ and $p<0.000)$.

\section{Discussion}

The research results on the demographic characteristics of the respondents obtained the results that most of the respondents $(90.3 \%)$ came from the Jatinangor campus. The Faculty of Nursing at Padjadjaran University consists of two campus locations, namely, Jatinangor and Pangandaran. Jatinangor campus is the main campus of the Faculty of Nursing. The majority of students from the 2016 Faculty of Nursing, Padjadjaran University, are female (90.3\%). These results have similarities with research conducted by Hurst (2015) showed that the proportion of female respondents was more than that of men, as many as 144 people (91.1\%) [14]. Therefore, gender is not a factor that affects the success of the learning process.

When viewed from the GPA, most of the respondents (95.1\%) obtained a GPA in the range of $3.00-4.00$. These results have similarities with research conducted by Nicholson (2010), who revealed that good learning would affect the GPA obtained by students. When viewed from the experience of attending seminars/workshops, most of the respondents $(61.1 \%)$ have never attended meetings/workshops on disaster management or disaster emergencies. In fact, by participating in training seminars/workshops, nurses have the provision and experience in dealing with conditions where disasters occur [15]. While those in charge of disaster management programs in West Java are mostly nurses [16], they work in community health centers that have an important role in disaster conditions [17]. Seeing this, nursing students should gain skills related to new knowledge and experience related to disaster nursing, increasing their confidence in providing treatment to disaster victims [18].

Based on the experience of experiencing a disaster, most of the respondents (81.9\%) have never experienced a disaster. A disaster experience is something that has been shared or felt in the past [19]. In research conducted by Putri dan Lestari (2018), $58 \%$ of respondents have experienced a disaster [20]. Respondents who have experienced disaster events tend to be better prepared to face disaster situations by actively participating in disaster training. This result is different from research conducted by most respondents $(81.9 \%)$ who have never experienced a disaster event and are not very active in participating in disaster training.

When viewed from the experience of being a disaster volunteer, most of the respondents (83.3\%) did not have experience as a disaster volunteer. These results are in line with research conducted by Ilham et al. (2016) revealed that it is difficult for nursing students to become disaster volunteers because they have to carry out professional education first if students have not carried out professional education they are not allowed to provide treatment to the victims [21]. Disaster volunteers are individuals who are involved in disaster situations as a relief team, both helping by raising funds to be distributed to victims, and some individuals are directly involved in emergencies to provide treatment to victims and reduce the impact of disasters [22].

Based on the results of the analysis that has been carried out, most of the respondents (97.9\%) revealed the need to do additional training to improve skills related to disaster nursing. These results align with Kaplan et al. (2012) research, which showed that simulation exercises could increase understanding related to disaster management, increase student competence in providing treatment to victims, satisfaction, and confidence [23]

Satisfaction is a feeling of pleasure that arises after comparing perceptions of performance (results) according to their expectations [24]. Student satisfaction is the basis for increasing student involvement in the learning process. When students are satisfied with the learning methods used, these students tend to participate in the learning process. Therefore, student satisfaction is the most important point when doing simulations [9].

The analysis of the relationship between the disaster simulation learning process and student satisfaction showed a significant relationship between the learning process and satisfaction. The value of $p<0.05$ and the value of $r=0.827$ indicate a positive correlation and the strength of the relationship is very strong. A positive sign indicates the better the learning process is applied; the students will feel more satisfied. In research conducted by D'souza et al. (2017) on 100 nursing, students showed a significant relationship between the simulation learning process and student satisfaction ( $p=0.03$ ) [25]. Thus, the simulation learning process directly increases student satisfaction and student knowledge and performance related to critical care and nursing care compared to students only learning by watching videos.

The results of other studies reveal that a good learning process with a variety of applied teaching methods makes nursing students in China feel satisfied with disaster simulation learning [26]. Disaster simulation learning positively affects student satisfaction because the learning process becomes more interesting, creative, and helps students prepare for disasters [1]. In addition, student satisfaction with the simulation learning method will affect the level of confidence when providing treatment to victims [27].

Self-confidence is an attitude that affects individuals when performing clinical tasks in a rapidly evolving emergency. Confidence is a crucial 
component in clinical decision-making and is essential for the practice of disaster simulation [28]. In addition, confidence will affect one's psychomotor skills in handling disaster victims [29], [30].

The analysis of the relationship between the disaster simulation learning process and student confidence showed a significant relationship between the learning process and self-confidence. The value of $r$ $=0.815$ indicates a positive correlation, and the strength of the relationship is very strong. A positive sign indicates that the better the learning process is applied; the students feel more confident. These results are in line with research conducted by Zhu dan Wu (2016), revealing that the simulation learning process has a positive relationship to student confidence [31]. Before students carry out simulations, the objectives and information related to the implementation of the simulation (tasks and roles, implementation time, scenarios, and processes) must be conveyed to students so that students can understand what must be done and become more confident when taking actions during the simulation implementation.

Students show a high level of confidence after doing the simulation. The simulation learning method makes the learning process more exciting and creative and helps students provide nursing care to patients during emergencies [1]. Another study revealed that learning real-time disaster simulations and using a human simulator can increase a person's confidence in providing treatment to victims and students feel more confident in solving problems during an emergency [28].

\section{Conclusion}

Based on the results of this study, the disaster simulation learning process has a relationship with satisfaction and self-confidence, where the strength of the relationship is very strong and positive. A positive relationship shows that the better the learning process is applied, the students will feel more satisfied and confident, and this will have an impact on the ability of students to respond to and handle real disaster conditions in the field. Knowing the existence of this relationship, lecturers must always pay attention to the learning process that is applied so that students are ready to become volunteers when disaster conditions do occur.

\section{References}

1. Omer T. Nursing students perceptions of satisfaction and self-confidence with clinical simulation experience. J Educ Pract. 2016;7(5):131-8.

2. Tuttle RE. The Impact of Simulation in Nursing Education on the Self-Efficacy and Learner Satisfaction of Nursing Students; 2009. p. 103

3. Jeffries PR, Rizzolo MA. Designing and Implementing Models for the Innovative Use of Simulation to Teach Nursing Care of III Adults and Children: A National, Multi-Site, Multi-Method Study. New York, United States: National League for Nursing; 2006. p. 1-17.

4. Zapko KA, Lou Ferranto M, Blasiman R, She D. Evaluating best educational practices, student satisfaction, and selfconfidence in simulation: A descriptive study. Nurse Educ Today. 2018;60:28-34. https://doi.org/10.1016/j.nedt.2017.09.006 PMid:2898789528987895

5. Sanford PG. Simulation in nursing education: A review of the research. Qual Rep. 2010;15(4):1006-11.

6. Putri TH. Menristekdikti: Perguruan tinggi harus punya program mitigasi bencana. Jakarta: IDN Times; 2019.

7. Tambak S. Metode ceramah konsep dan aplikasi dalam pembelajaran pendidikan agama islam. J Tarb. 2014;21(2):375-401.

8. Nicholson AC. Comparison of selected outcomes based on teaching strategies that promote active learning. Clin Simul Nurs. 2010;5(3):S11.

9. Sinclair B, Ferguson K. Integrating simulated teaching/learning strategies in undergraduate nursing education. Int J Nurs Educ Scholarsh. 2009;6(1). https://doi.org/10.2202/1548-923x.1676 PMid:2898789519341357

10. de Oliveira Costa RR, de Medeiros SM, Coutinho VR, Mazzo A, de Araujo MS. Satisfaction and self-confidence in the learning of nursing students: Randomized clinical trial. Esc Anna Nery. 2020;24(1):1-9. https://doi. org/10.1590/2177-9465-ean-2019-0094

11. Hart PL, Spiva LA, Mareno N. Psychometric properties of the clinical decision-making self-confidence scale. J Nurs Meas. 2014;22(2):312-22. https://doi.org/10.1891/1061-3749.22.2.312 PMid:2898789525255681

12. American Association of Colleges of Nursing (AACN), Faculty Shortages in Baccalaureate and Graduate Nursing Programs: Scope of the Problem and Strategies for Expanding the Supply; 2005.

13. Wall BM. 2013 Hannah lecture. Disasters, nursing, and community responses: A historical perspective. $\mathrm{N}$ urs Hist Rev. 2015;23(1):11-27.

14. Hurst KS. High Fedelity Simulation: Its Impact on SelfConfidence and Satisfaction in Learning Among Sophomore and Senior Students; 2015.

15. Emaliyawati E, Ibrahim K, Trisyani $\mathrm{Y}$, Mirwanti R, Ilhami FM, Arifin $H$. Determinants of nurse preparedness in disaster management: A cross-sectional study among the community health nurses in coastal areas. Open Access Emerg Med. 2021;13:373-9. https://doi.org/10.2147/oaem.s323168 PMid:2898789534385845

16. Emaliyawati E, Prawesti A, Yosep I, Ibrahim K. Manajemen mitigasi bencana dengan teknologi informasi di kabupaten ciamis. J. Keperawatan Padjadjaran. 2016;4(1):79-89. https:// doi.org/10.24198/jkp.v4i1.139

17. Widiasih R, Ermiati E, Emaliyawati E, Hendrawati S, Susanti RD, Sutini T, et al. Nurses' actions to protect their families from COVID-19: A descriptive qualitative study. Glob Qual Nurs Res. 2021;8. https://doi.org/10.1177/23333936211014851 PMid:2898789533997120

18. Alrazeeni D. Saudi EMS students perception of and attitudes toward their preparedness for disaster management. J Educ Pract. 2015;6(35):110-6.

19. Havwina T, Maryani E, Nandi N. Pengaruh pengalaman bencana terhadap kesiapsiagaan peserta didik dalam 
menghadapi ancaman gempabumi dan tsunami. J Geogr Gea. 2017;16(2):124. https://doi.org/10.17509/gea.v16i2.4041

20. Putri FA, Lestari F. Student Perceptions of Faculty of Medicine, Dentistry, Nursing, and Pharmacy University of Indonesia in Facing Disaster as Efforts to Enhance Resilience in University 2017. Vol. 4. Dubai: KnE Life Sciences; 2018. p. 462. https://doi. org/10.18502/kls.v4i5.2577

21. Ilham J, Mulyadi M, Imran I, Syahrul S, Mudatsir M. Evaluasi Partisipasi Pendidikan Kebencanaan Pada Mahasiswa Fakultas Kedokteran Universitas Syiah Kuala (Setelah Mengikuti Blok Disaster Management). J Kedokt Syiah Kuala. 2016;16(3):14652. https://doi.org/10.52574/syiahkualauniversitypress.361

22. Wall BM, Keeling AW. Nurses on the Front Line: When Disaster Strikes, 1878-2010. Berlin, Germany: Springer Publishing Company; 2010.

23. Kaplan BG, ConnorA, Ferranti EP, Holmes L, Spencer L. Use of an emergency preparedness disaster simulation with undergraduate nursing students. Public Health Nurs. 2012;29(1):44-51. https:// doi.org/10.1111/j.1525-1446.2011.00960.x PMid:2898789522211751

24. Asmuji A. Manajemen Keperawatan Konsep dan Aplikasi. Yogyakarta: Ar-Ruzz Media; 2012.

25. D'souza MS, Venkatesaperumal R, Chavez FS, Parahoo K, Jacob D. Effectiveness of simulation among undergraduate students in the critical care nursing. Int Arch Nurs Health Care. 2017;3(4):084. https://doi.org/10.23937/2469-5823/1510084
26. Xia S, Yang B, Chen X, Petrini MA, Schory SA, Liu Q. Application and effects of a disaster nursing simulation training for Chinese undergraduates. J Nurs Educ Pract. 2016;6(10):6.

27. Alim S, Kawabata M, Nakazawa M. Evaluation of disaster preparedness training and disaster drill for nursing students. Nurse Educ Today. 2015;35(1):25-31. https://doi.org/10.1016/j. nedt.2014.04.016

PMid:2898789524832532

28. O'Donnell JM, Decker S, Howard V, Levett-Jones T, Miller CW. NLN/Jeffries simulation framework state of the science project: Simulation learning outcomes. Clin Simul Nurs. 2014;10(7):373-82. https://doi.org/10.1016/j.ecns.2014.06.004

29. Baillie L, Curzio J. Students' and facilitators' perceptions of simulation in practice learning. Nurse Educ Pract. 2009;9(5):297306. https://doi.org/10.1016/j.nepr.2008.08.007 PMid:2898789518842463

30. Barsuk JH, Cohen ER, Feinglass J, McGaghie WC, Wayne DB. Use of simulation-based education to reduce catheter-related bloodstream infections. Arch Intern Med. 2009;169(15):1420-3. https://doi.org/10.1001/archinternmed.2009.215 PMid:2898789519667306

31. Zhu FF, Wu LR. The effectiveness of a high-fidelity teaching simulation based on an NLN/Jeffries simulation in the nursing education theoretical framework and its influencing factors. Chin Nurs Res. 2016;3(3):129-32. https://doi.org/10.1016/j. cnre.2016.06.016 